Meta

Journal des traducteurs

Translators' Journal

\title{
Translating Cultural Difference: Fakir Mohan Senapati's Chha Mana Atha Guntha
}

\section{Paul St-Pierre}

Volume 42, numéro 2, juin 1997

Lexicologie et terminologie II (1) et Traduction et post-colonialisme en Inde

Translation and Postcolonialism: India (2)

URI : https://id.erudit.org/iderudit/004300ar

DOI : https://doi.org/10.7202/004300ar

Aller au sommaire du numéro

Éditeur(s)

Les Presses de l'Université de Montréal

ISSN

0026-0452 (imprimé)

1492-1421 (numérique)

Découvrir la revue

Citer cet article

St-Pierre, P. (1997). Translating Cultural Difference: Fakir Mohan Senapati's Chha Mana Atha Guntha. Meta, 42(2), 423-438. https://doi.org/10.7202/004300ar

\section{Résumé de l'article}

Une analyse de quatre traductions vers l'anglais du roman indien Chha Mana Atha Guntha (littéralement : "Six acres et trente-deux décimaux"), paru vers la fin du XIXe siècle, montre que les traducteurs optent pour des stratégies diverses, y compris la non-traduction, lorsqu'ils ont à traiter de certains aspects particuliers à la culture source. Les choix du traducteur ont pour effet de créer un nouveau texte, mais aussi un nouveau public; de ces choix découle donc une variété de textes et de publics. Les différences entre les œuvres examinées révèlent la complexité de la traduction des textes indiens vers l'anglais, langue de l'ancienne puissance coloniale, ainsi que la façon dont ces langues réinventent leurs relations dans un contexte post-colonial.
Ce document est protégé par la loi sur le droit d'auteur. L'utilisation des services d’Érudit (y compris la reproduction) est assujettie à sa politique d'utilisation que vous pouvez consulter en ligne.

https://apropos.erudit.org/fr/usagers/politique-dutilisation/ 


\title{
TRANSLATING CULTURAL DIFFERENCE: FAKIR MOHAN SENAPATI'S CHHA MANA ATHA GUNTHA'
}

PAUL ST-PIERRE

Université de Montréal, Canada

\begin{abstract}
Résumé
Une analyse de quatre traductions vers l'anglais du roman indien Chha Mana Atha Guntha (littéralement: «Six acres et trente-deux décimaux»), paru vers la fin du XIX ${ }^{e}$ siècle, montre que les traducteurs optent pour des stratégies diverses, y compris la non-traduction, lorsqu'ils ont à traiter de certains aspects particuliers à la culture source. Les choix du traducteur ont pour effet de créer un nouveau texte, mais aussi un nouveau public; de ces choix découle donc une variété de textes et de publics. Les différences entre les ouvres examinées révèlent la complexité de la traduction des textes indiens vers l'anglais, langue de l'ancienne puissance coloniale, ainsi que la façon dont ces langues réinventent leurs relations dans un contexte post-colonial.
\end{abstract}

\begin{abstract}
The analysis of four translations into English of the late nineteenth-century Indian (Oriya) novel Chha Mana Atha Guntha (literally: Six Acres and Thirty-Two Decimals) shows that translators, faced with references to specific aspects of the source culture, may use a variety of tactics, including non translation, as a part of their overall strategy. The choices translators make not only result in a new text but also construct a new readership, and these choices, texts, and readerships can and do vary. The differences between the translations examined reflect the complexity involved in the translation into English, the language of the former colonial power, of Indian-language texts, and the diverse ways in which these languages can reinvent their relations in a postcolonial context.
\end{abstract}

The very purpose of translation - its "carrying across" texts between cultures ${ }^{2}$ raises the question of the extent to which communication is possible from one culture to another and of what is or can be communicated. If there are limits to transmissibility, and if these limits are social, cultural and historical in nature, then the translation of texts is put into question by the obligation to translate. In other words, translation is made necessary by the fact that cultures and languages differ, but it is also made difficult by this very difference. ${ }^{3}$ Made "difficult" but not "impossible", unless of course by "translation" is understood the unmediated re-presentation of an original text, a definition of translation which can only ensure that to translate is to fail. As Carol Meier writes (Meier and Dingwaney 1995: 21): "Translation [...] implies not so much (failed) exchange as (problematic) interchange that should not automatically be defined as loss." But even with a clear understanding of the transformation that all translation involves, translation remains difficult, since the negotiation of cultural, temporal and linguistic differences - to mention only these - always takes place in a space which is never neutral. This is clear enough from the experience of translation in Canada, where a number of studies have underscored the value-laden nature, the ideological role, of translation. ${ }^{4}$ The "space" of translation is one in which interaction with other cultures takes place, or in certain cases does not take place, a space in which power relations between these cultures are played out. ${ }^{5}$ 
The purpose of this paper is to attempt to describe some of the complexities involved in this intercultural negotiation, taking as my example translations into English of a major literary text written in Oriya, the language of Orissa, an eastern coastal state of India. What I will attempt to demonstrate is that certain cultural references function in the English translation primarily as markers of origin and in so doing serve to hybridize language and space, reflecting a plurality of possible readerships, and, within these readerships, the effects of colonization on both the colonizers and the colonized. The play between the explicit and the implicit, in the original text itself but more especially in the relations between the original and its translation, connects them directly to history, through the rewriting of a text produced under and marked by British colonial rule and its insertion through translation into a postcolonial context. As we will see, however, through an examination of the differences between the translations, what is designated here as " $a$ postcolonial context" is itself open to question insofar as it implies a certain oneness of experience. What the different translations point to, in fact, by the very differences which exist between them, is a variety of experience and a range of contexts.

That the translations are into English is of great importance, bringing to the fore as it does certain of the ambiguities surrounding the use of English in India: ${ }^{6}$ English is the language of the courts in India and of higher education, the language of an elite - and of an ever-growing would-be elite; despite this, English is not one of the languages given full constitutional recognition under the Indian constitution, having associate status only; it is the language of the former colonial power, and yet it is also a language considered sufficiently neutral to be chosen as the official state language of Nagaland, an eastern state bordering on Burma, where a plurality of languages compete for recognition; it is the language in which more and more primary and secondary schooling is taking place albeit still of a minority of students, and it is a language which marginalizes the greater part of the population of the country; English is the language used most frequently as a link-language between the various Indian languages, and it is also the language of a certain number of major Indian (or, Indo-Anglian) writers. English is also an Indian language, ${ }^{7}$ and the choice of which English to use corresponds to a choice of intended readerships. As Gayatri Spivak remarks concerning the objection that her translations of Mahasweta Devi's short stories are not sufficiently accessible to Indian readers (Devi 1995: xxviii): "I am aware that the English of my translations belongs more to the rootless American-based academic prose than the more subcontinental idiom of my youth. This is an interesting question, unique to India: should Indian texts be translated into the English of the subcontinent?" Without wishing to go further here into the question of the choice of English (or, englishes) into which to translate, ${ }^{8}$ the comparison of the different translations will lead us to attempt to determine the implied readers for whom they are intended.

\section{CHHA MANA ATHA GUNTHA, A NOVEL BY FAKIR MOHAN SENAPATI}

The work whose translations will be discussed is a celebrated late nineteenth-century novel by Fakir Mohan Senapati, Chha Mana Atha Guntha (literally: Six Acres and Thirty-Two Decimals). Serialized between 1897 and 1899, the novel is considered a founding text of Oriya literature and the first social-realist novel to appear in any Indian language. Despite the recognition given it in Orissa as one of the greatest texts of Oriya literature, the novel nevertheless remains at a temporal, cultural and linguistic remove from its readers. This distance is both one of tone and of language: the duality inherent in the narrative voice serves to create such an ironic distance between text and reader; yet another form of distance, more linguistic in nature, is that created by the text's use of non-sanskritized, colloquial Oriya rather than the more "elevated" forms usual in literature, with the result that the text, the original text, contains words and expressions which 
require explanation and footnotes for the modern-day Oriya reader. Indeed, the difficulty which the original poses for such readers will very likely lead many of them to have access to the text solely through its English translation. ${ }^{9}$

The novel recounts the rapacious greed of the main character, Ramachandra Mangaraj, and of his mistress, Champa, their lust for a small plot of land - the six acres and thirtytwo decimals mentioned in the title, and their ultimate downfall; she is murdered by a fellow thief and Mangaraj is dispossessed, just as he dispossessed many others, at the hands of an unscrupulous lawyer. The theme of the manipulation of the legal system - introduced by the British - is constant throughout the novel and a moving force behind the unfolding of events. But of greater interest than the bare storyline, is the manner in which the story is told, especially its satirical tone, which creates a relation between the narrator and his tale such that as the narrator tells the story his comments lead us to hear another, contradictory voice, calling into question much of what he affirms and all forms of authority, creating a "critical" distance informing the novel as a whole. An illustration of this can be found in the first chapter, where the narrator discusses the suggestion that Mangaraj is not as pious as he might otherwise seem, that he does not fast as he pretends to do on the holy days:

Just the other afternoon, Jaga, Mangaraj's barber, let it slip that on evenings of ekadasi a large pot of milk, bananas, and a small quantity of khai and nabata are kept in the master's bedroom. The following mornings, very early on dwadasi, Jaga removes the empty pot and washes it. Hearing this, some exchanged sly looks and chuckled. One blurted out, "Even the father of Lord Mahadeba can't catch a clever fellow stealing a drink of water after dipping into it." What this meant was not entirely clear to us, but we guess these men were slandering Mangaraj. Ignoring their intentions for the moment, we would rather plead the master's case thus: Produce the eye-witness who has seen Mangaraj emptying the pot. Like judges in a court of law, we are absolutely unwilling to accept hearsay and conjecture as evidence. Moreover, science textbooks state unequivocally: "Liquids evaporate." Milk is a liquid. Why should milk in a landlord's household defy the laws of science? Besides, in the landlord's bedroom there were moles, rats, and bugs; and in whose house can mosquitoes and flies not be found? Like all base creatures of appetite, they are always looking for food. For such creatures are not spiritually-minded like Mangaraj, who had the benefit of listening to the holy scriptures. Hence it would be a great sin to doubt Mangaraj's piety or sincere devotion - this we firmly believe.

In this passage the mere accumulation and juxtaposition of arguments, supposedly in Mangaraj's favour, serve to discredit him; in the end readers are led to associate him with the moles, rats, bugs, mosquitoes and flies with which he shares his bedroom. The satirical tone present here, having as its target not only Mangaraj but the judges in the lawcourts as well, and even the texts of science and holy scripture, is a constant feature of the novel, which takes aims at all sectors of society and most especially those whose power oppresses the weak. ${ }^{10}$

For our purposes the focus in this paper will be placed on the opening sentences of the novel, which, in the present version of our translation, ${ }^{11}$ read as follows:

Ramachandra Mangaraj was a rural landlord, and a prominent moneylender as well. His transactions in grain far exceeded those in cash. For an area of four kos around no-one else's business could thrive. The man was also quite pious. There are twenty-four ekadasis in a year; if there were forty, he would not have ignored a single one - this we need to acknowledge. He fasted every ekadasi and took nothing but water and a few leaves of the sacred basil plant for the entire day.

In this translation, two Oriya words - kos, a measure of distance, and ekadasi, a day of religious observance - are used, and their non-English origin emphasized by the use of 
italics. These foreign terms mark the location of cultural difference within the text, and what will now be examined is the necessity of marking this difference at these particular places in the text, and the effect of marking it in this particular way.

\section{IDENTIFYING THE FOREIGN}

Let us briefly look at the two italicized terms - kos and ekadasi — in the passage under scrutiny.

kos:

The Hanklyn-Janklin, a dictionary whose subtitle presents it as "a stranger's rumbletumble guide to some words, customs and quiddities Indian and Indo-British," defines kos as a "[m]easure of length: a distance of between two and two-and-a-half miles. Used today only in rural India." The Hobson-Jobson, a "glossary of colloquial Anglo Indian words and phrases, and of kindred terms, etymological, historical, geographical and discursive," first published in 1886 and republished a hundred years later, devotes more than a page to coss and its variant forms (krosa in Sanskrit, a measure of distance originally signifying a "call", and course, as it was often written by early English travellers). Coss, cos, kos and course also figure in Sahibs, Nabobs and Boxwallahs, yet another dictionary of "the words of Anglo-India." Kos is found in general English dictionaries as well, for example the Collins English Dictionary, with the additional spelling coss, and the Oxford English Dictionary, which provides five additional transliterations (cos, course, courss, cose, koss), and defines the term as "A measure of length in India, varying in different parts from 2-and-a-half miles or more down to about 1-and-a-quarter." The existence of these different forms underscores a certain instability in the relations between the Indian languages and English over time, a tension between the tendancy of English to assimilate (thus the use of the spelling course as early as 1616) and the claims of the foreign languages, be they Oriya, Hindi or Sanskrit. The number of different spellings, of different representations of Indian languages, ${ }^{12}$ are a witness to the complicated history and prolonged contacts, and misunderstandings, between England and India. Designating a specifically Indian reality, kos has nevertheless made a partial and hesitant entry into English. Indeed, the definition in the Oxford English Dictionary underscores the Indian origin of the word while including it as part of the English lexicon. That this lexicalization concerns a unit of measurement is also of a certain importance, since the colonial project often involved the imposition of form on an area which the colonizers otherwise considered as formless. This is reflected in the numerous attempts by the British to calculate, measure and take an inventory of the diversity, the richness of India. One such project was the survey of Indian languages carried out by Grierson between 1898 and 1927, and the translation of the classic texts of Indian philosophy and literature begun in the late eighteenth century could also be considered in this light. These various undertakings, while often undeniably resulting in beneficial effects, nevertheless also constituted attempts on the part of the colonizers to appropriate and to extend their mastery. Indeed, many such projects, and in particular the translations, were undertaken at the express request of the East India Company in the hope they would enable it to govern more efficiently.

\section{ekadasi:}

The Hanklyn-Janklin defines ekadasi (transcribed as ekadashi) as follows: "One plus ten: for Hindus, the eleventh day of each lunar fortnight (see Calendars): i.e. the third or fourth day before both the full and new moons. The devout fast on these days (see Fasting); days particularly dedicated to the worship of Lord Vishnu." The term is also found in Sahibs, Nabobs and Boxwallahs under the same transcription, and is defined as 
"[t]he eleventh day of either fortnight in a lunar month on which Hindus fast." If, unlike kos, ekadasi has not been lexicalized in English it is most likely precisely because of its more direct connection to India: in addition to the mention of Lord Vishnu and the introduction of the definition by the particularizing expression "for Hindus", note the referral by the Hanklyn-Janklin to other dictionary entries which in turn situate as Indian realities ('calendars' and 'fasting') whose specificity might otherwise not be acknowledged. Ekadasi also figures in the Indian English supplement to the Oxford Advanced Learner's Dictionary of Current English.

Kos and ekadasi thus correspond in different degrees to what can be considered Indian realities, and their lexicalization, or lack of it, reflects the degree to which such realities have affected those of the colonial power. Certain questions remain, however, after this brief examination, most notably: 1) does the fact that these terms relate to such "foreign" realities necessarily make them untranslatable, ${ }^{13}$ and 2) are there other terms in this passage which also relate to such realities but which nevertheless have been translated? The answers to these two questions will lead us in the next section of this paper to reflect on the effect and function of such untranslated, if not untranslatable, terms.

\section{CULTURAL SPECIFICITY AND TRANSLATION}

With regards the translatability of the two terms, an examination of the three published translations of Chha Mana Atha Guntha can provide us with certain answers. ${ }^{14}$

In the translation by B. M. and A. M. Senapati, the distance designated by the term $k o s$ is converted into an imperial measure ("within a radius of eight miles") and the reference to the religious holy day is maintained as a foreign word in the text (Ekadashi). In the version by C. V. Narasimha Das, The Stubble Under the Cloven Hoof, the translator adopts a different strategy with regards the day of fasting, that of including and explaining the foreign term within the text of the translation itself:

There are two Ekadasi days in the course of each month of the Hindu calendar, one coming up during the dark fortnight and the other during the bright fortnight. It follows, therefore, that there are twenty-four Ekadasai days in all the year; and it is around them that a good deal of Hindu piety collects itself generally.

This extended gloss is in keeping with the translator's strategy of expanding the original to include within the text itself all manner of explanation and allusion. As for kos, Das too substitutes English for Indian measures ("over eight long miles around that village"). Finally, Nuri Misra, in his translation, A Plot of Land, renders ekadasi by "fasting days" ("He was a pious man and observed all 24 fasting days around the year") and kos by the Sanskrit krosas. These two terms are thus given different treatment in the various translations. Two of the three adopt the imperial system of measurement and substitute 'miles' for $k o s$. As for ekadasi, the translators' choices reflect different options. The use of the generic "fasting days" by Nuri Misra maintains to a certain degree the semantic content, but at the expense of specific cultural reference, whereas C. V. N. Das keeps the precise term as does the translation by A. M. and B. M. Senapati - while also providing an explanation for non-Indian readers.

With regards the question as to whether there are in this opening passage other equally culturally-specific terms, at least three can be mentioned. The first and last sentences of this passage in the translation by B. M. and A. M. Senapati reads: "Ramchandra Mangaraj was a mofussil Zamindar," "On the day of the Ekadashi fast, he partook only of the leaves of sacred Tulasi with water." Neither of the other two published translations uses mofussil, one contains the term zamindar, and both use a form of tulsi (tulsi and Tulasi). The 
translation in preparation (the first passage cited in Appendix 1) substitutes 'landlord' for zamindar, 'rural' for mofussil, and 'the sacred basil plant' for tulsi. All three Indian terms - mofussil, zamindar and tulsi — can be found in the Oxford English Dictionary, and zamindar (or zemindar) is an entry in the Webster's New Collegiate, the American Heritage Dictionary of the English Language, and the Collins English Dictionary as well. It is therefore possible to imagine at least two additional translations of the passage: the first would contain no words which could be specifically tied to India but only their more generic English substitutes (passage 5 in Appendix 1); in the second, Indian terms would be used wherever possible (passage 6). Such versions would constitute the extremes of eliding or underscoring cultural difference, the two poles between which the translations actually produced variously locate themselves. Since such different and extreme choices are possible, all of the translations appear as the result of choices or compromises operated by the particular translators rather than as the products of cultural difference inexorably imposing itself. The decision to maintain or to appropriate certain terms is part of an overall translation strategy, and corresponds not only to a vision of the original work but also to a more or less precise conception of the readers for whom the translations are intended.

There is also another effect of marking certain terms in the translation as untranslatable. Doing so has the result of marking all others as translatable and, what as more, as correctly translated; it serves to attest to the possibility of transmissibility and to the validity of the particular translation being read. Cultural difference is underlined, but it is specifically located; in the case of the translation with which we started this discussion, kos and ekadasi might remain inaccessible to potential readers but the lack of transparency appears to be reducible to these concepts alone. The use of 'rural' is thus considered an acceptable alternative for mofussil, despite the loss of any reference to the system of the presidencies under British colonial rule, the heritage of the East India Company, and the exploitation of Orissa by the Bengalis, pointed to in the footnote to mofussil in the translation by B. M. and A. M. Senapati. If need be, these references to the history of India could be reconstituted in the English version, but what is significant here is that such a need is not felt. The decision to use Indian terms thus seems to depend less upon the desire to convey specific meanings than to point to a particular time and place: these terms point back to the origin of the text, and forward to its intended readers. Back, since these terms are signs whose meaning poses no particular problem for readers since at least the general sense can easily be deduced from the context or determined by consulting English-language dictionaries. But such untranslated terms cannot be reduced to the state of pure signifieds: another reality, a certain resistance to the reality into which the translated text transports them, is present here, insofar as these are signs from another linguistic system, which is what they remain despite their lexicalization in certain cases. Their foreignness is further emphasized through the use in some cases of italics, underscoring the duality within the translation, the copresence of cultures and languages. These terms function in a way similar to that of proper names, which do not usually have other than residual meaning and fulfill what is essentially a referential (indexical) function. However, as Lévi-Strauss (1961) has remarked in La Pensée sauvage, names do nevertheless produce meaning through their classificatory function; from the classfication they operate meanings accrue. Thus, in the case of the main character, Ramachandra Mangaraj, whose name is given in the opening passage of the novel, the stability of his name, its lack of "translation", points back to the original context. It is an "Indian" name, and as such it re-marks, within English, the non-English origins of the story being told. Proper names thus work alongside the foreign words, italicized or not, to create a hybrid space which is other than that of a work written directly, originally in English. This space, which 
is precisely that of translation, is, according to Carol Meier, a space of inquiry: the end of translation, she writes, is to prompt inquiry "and to further investigation of how apparently inexplicable things might be comprehended without making them explicable in familiar terms (and without allowing them to appear simply different)" (Meier and Dingwaney $1995: 31$ ). This is indeed the tension which can be felt in these translations of Fakir Mohan: to neither make the original a seamless English text nor to make it an inaccessibly foreign text, but rather to play with familiarity and foreignness so as to produce a translation in which they intermingle. This hybridity is specific not only to translation but also to the post-colonial context. Maintaining within the translation the coexistence of the different spaces is a way of recognizing the effects of India upon English and of English upon India, a way of inscribing the text and its translation within the colonial and the postcolonial experience, notably through the use of language, where such contact is actualized, and through the construction of the intended reader for the text produced.

\section{CULTURAL ALLUSIONS}

Differences between cultures are not located exclusively on the lexical level. The first chapter of Chha Mana Atha Guntha contains several allusions to cultural practices and sacred texts, and these receive different treatment in the four translations.

The first such allusion (Appendix II, passage 1) is to the miracle recounted in the Bible of the multiplication of the loaves and the fishes, an event which is compared to an episode from the Mahabharata in which Lord Krishna feeds a multitude of people with a small amount of food. ${ }^{15}$ The parallelism established between the two traditions testifies to the presence and activity of British and other European missionaries in India during the nineteenth century, and what is striking about it is the variation in the translation of the Biblical reference and the relative stability in the representation of the Indian text. This is particularly the case in the account of the biblical miracle, where the number of people fed is variously given as thousands, twelve hundred, and five thousand, whereas all translations refer to the number of Durbasa's disciples as twelve thousand. Nor do the translations indicate in the same way the amounts of food required to feed the multitudes ("two pieces of bread", "a few loaves", "five barley loaves and two fishes", "two loaves"). There is similarly some variation in the reference to Lord Krishna ("morsel of food", but also "a green edible" and "a sprig of spinach").

The comparison of the different translations of the passage can tell us a number of things. The first remark to be made is in relation to Fakir Mohan's rewriting of the Biblical text. As can be seen by the comparison of the literal translation of the original text with the Biblical story (see notes 15 and 16), the author has not only changed certain details (the amount of bread, the number of people, the amount of food left over), he has also eliminated others (omitting reference to the fish, for example). This rewriting of the story by the author evidently posed certain problems for the translators, whose versions tend to gloss over the differences. In Nuri Misra's translation, for example, the precise figure of twelve-hundred is increased to "thousands", and in that of A. M. and B. M. Senapati, two pieces of bread become "a few loaves". Both translators thus tend to minimize the differences between the literary and the Biblical texts, without however introducing blatant changes. Such is not the case, however, with the "corrections" introduced by C. V. Narasimha Das in his translation, where the recounting of the miracle is explicitly reconstructed along the lines of the account in the Bible. ${ }^{16}$ The reference in the translation to the "Gospel of St. John" and the addition of the Biblical "O ye of little faith" introduce the translator's reworking of Fakir Mohan's rewriting of the original source. What takes place here in the translation into English is the erasure of the transformation carried out by Fakir Mohan. The "correction" by the translator not only re-establishes the "truth" of 
the biblical text, it also re-introduces the dominance of the European colonial tradition over Indian writing.

There is a second reference in this chapter which again brings the two traditions into relation, ${ }^{17}$ both Christ and Sita having been slandered and maligned and having suffered fates they in no way deserved. What is of interest here is the way in which Sita, the consort of Rama whose abduction and rescue form the central events of the Ramayana, is referred to in the translations. That by Nuri Misra does not qualify the name, whereas the others all contextualize the reference. Qualified as "the incarnation of chastity" in the translation by B. M. and A. M. Senapati, and as "the paragon of chastity" by C. V. Narasimha Das, who adds to the name the epithet "Mother", Sita is referred to as "Goddess" in the translation by R. S. Mishra et al. Such interventions serve to indicate the importance of the reference to readers who might otherwise fail to understand its significance, and thereby underscore the change of context brought about by the translation.

There is an additional cultural allusion in the chapter, in the passage recounting the misadventures of Mangaraj's relative Shyama Malla. ${ }^{18}$ Here, the variation between the different translations is particularly great. Thus Mangaraj's "cousin"/"cousin brother" goes to "town"/or to "Cuttack" and eats either "cabbage" or "cauliflower" with onions (the important element of this account, the source of Shyama Malla's misfortunes, the eating of onions, remains constant in all the translations). The possible result of this act is that Shyama "would have been excommunicated," a curiously Christian (Roman Catholic) expression which resituates Hindu practices in terms of something possibly more familiar to the readers of the translation, "would have been cast out of society" (a generic characterization of what was a specific event), "would have been fated to live the life of a second Cain with a stigma on his face in the form of an outlawed beard unshaven by the village barber" (here the Christian and the Hindu traditions are once again brought together, and the Hindu practice made clear through the use of "stigma" and "outlawed"). Finally, in the fourth translation - "his face would be covered even now with ugly stubble, a mark of penance" - the reference is clarified through the addition of "the mark of penance." As well, in the translation by C. V. Narasimha Das, a reference to Wordsworth has been added, whose principal function seems to be to provide a familiar signpost for readers who might otherwise lose their way amidst cultural difference.

\section{THE INTENDED READERS}

We have already noted the importance of the colonial experience in defining the original text. As L. Sahu writes in his "Introduction" to the translation by B. M. and A. M. Senapati (1967: 7):

Sarcastic satire on the shortcomings of contemporary society and some trenchant criticism of British exploitation are features of the novel [...] In particular he [Fakir Mohan] brought out the tragic details of a legal and administrative system under which many poor people lost their all, fleeced by greedy landlords, clever lawyers and unscrupulous policemen, etc.

In the case of this version, the "Translators' Note" sets out the purpose of the translation and identifies the readers for whom the translators are writing (1967:8):

We have made the English translation as true to the original as practicable. We hope this will facilitate, among the reading public of this vast sub-continent of India, a closer understanding of life in Orissa in the last century; in so doing it may promote that unified view of Indian life which is unmistakable in spite of the rich diversity of our country.

The translation into English is thus given the purpose of reaching other Indian readers. The publication of the translation by the Publications Division of the Government of 
India, however, because such publications are more widely distributed and readily available outside India than within, insures that the actual readers of the translation are more likely to be European or American than Oriya or Indian. This aim of reaching Indian readers is also somewhat called into question by the inclusion of a glossary appended to the translation, which does not include merely "[t]erms and expressions which are local or bear the stamp of local atmosphere" (1967:8), as the translators claim, but also those which would be familiar to all Indian readers: the names of the months (Aswina, Bhadra, Chaitra, etc.) or of the days (ekadasi, jamastami) in the Hindu calendar, forms of address (Saant, Saantani), terms relating to religious worship (tulasi, tulasi choura, Vaisnava), as well as those more specifically relating to Orissa.

The opening passage of the novel is one of two in this translation which is footnoted. The second, on page 99, explains the origins and the evolution of the Supreme Court, founded by the East India Company. The footnote at the very beginning of the text defines the term mofussil and in so doing alludes to the history of Orissa and its at times difficult relations with Bengal. Strictly speaking, mofussil refers to the countryside as opposed either to the Presidencies under British colonial rule (Calcutta, Bombay, Madras) or to the seat of the district authorities (Hobson-Jobson 1994: 570). The reference in the note to the translation to the "many big ('absentee') landlords who lived in the metropolis, Calcutta, or at least in big towns like Cuttack" adds to the centre/periphery distinction an allusion to the actions of Bengalis in Orissa during the nineteenth century, when, while remaining in Calcutta, Bengalis bought up large tracts of land in Orissa, leaving the inhabitants without the means to survive. J. K. Samal describes the situation as follows (1989: 12-13):

The security of the Government revenue depended upon the sales of estates for arears of revenue. [...] [T] he number of estates which are [sic] put up to sale between 1805 and 1819 was incredibly large. The defaulting estates were sold at Cuttack and many old Oriya families were ruined. [...] Most of the estates were bought by speculative Bengalis who expected permanent settlement to be made in Orissa. This led to the extinction of the Oriya zamindars as the predominating class of land holders in Orissa. They were supplanted generally by Bengalis who were sometimes wealthy absentees [...] The introduction of the absentee Bengali element was to exercise ultimately a ruinous effect on cultivation.

Here too then a contradiction between stated aims and actual practice seems to exist: by the emphasis placed on the contentious relations between Oriyas and Bengalis the promotion of a "unified view of Indian life" is somewhat undermined.

A second translation of Chha Mana Atha Guntha, this one by C. V. Narasimha Das, also appeared in 1967. Its dedication clearly situates the translation within the realm of English studies, where the English language will serve the purpose of making texts written in Indian languages known outside their language groups:

Dedicated to All the ill-paid Indian teachers of English who smile sceptically at Research in English studies in India, but believe passionately in harnassing the English language to deliver the national goods of which Research usually knows nothing.

The translation is in fact presented as a rewriting of the original work and is almost three times as long as the other published translations. As the translator writes:

Fakir Mohan himself, I fancy, would have written something vitally like this book if he had come to write in English today. He would have poured his genius, which chiefly means his hilarity, into such as English mould as this; and a star would then have risen in the firmament of Indo-Anglian fiction [...]. (1967:i)

Through the translation Fakir Mohan becomes an Indian author writing directly in English, and Dr. Johnson's remarks on Pope's translation of The lliad are quoted in support of the 
undertaking. ${ }^{19}$ The translator considers his work (he signs as "the author" 20 ) an illustration of his "faith that English literature can enrich an Indian vernacular tale by teaching him who retells it in English the art of rechristening its thought and imagery and giving it an Indo-Anglian domicile in the commonwealth of letters." (1967 : iii) As a result his translation and rewriting of the original work "symbolically amounts to the cultivation of a literary habit which the role of the English language in New India seems to call for." (1967: iii)

In his "Introduction" to the novel, Das stresses "the dignity and nobility of the British Indian jurisprudence which we, the citizens of Independent India of today, have received as an invaluable heritage from the British rule." (1967: iii) Indeed, the translator stresses the lesson to be learned from the novel by modern-day India: that an "emotional approach of a people to the law gives a true vitality to all their public conduct" (1967:v) and just as socialist thinkers in India wish to appropriate English-held property as national property, so too the translator wants to call national "the bridge named the English language." (1967: vi)

The novel is placed under the auspices of Charles Dickens, through a quotation added by the translator to the inside title page ("I am a fond father to every child of my fancy") and the first chapter begins with a passage, also added by the translator, from Shakespeare's The Merchant of Venice, a passage which serves to make explicit the moral of the tale, a moral which in fact is amply clear in the novel itself and in the satirical tone of the narrator. The decision to quote Shakespeare is thus symbolically rather than semantically important, coming as it does from a professor of English in India. As Harish Trivedi has shown, the reaction to Shakespeare's texts in India is particularly significant, a litmus test for the colonial and postcolonial relations between Britain and India. ${ }^{21}$ Here the novel being translated serves to illustrate the illustrious authors of the canon of English literature: Dickens, Shakespeare, Dryden, Spenser, Swift, etc., all of whom are quoted at the heads of chapters.

In the opening passage of the novel in Das's version, cultural difference is handled in a number of ways: it is explained - "there are twenty-four Ekadsai [sic] days," adapted _ " "over eight long miles around," elided — there is nothing in the translation which corresponds to mofussil, or defined - "the Tulasi leaf, (that is, the Indian basil)." And while certain of the additions the translator makes to the text are references to specifically Indian realities, they are no sooner used than defined: "the Samant (we mean Mangaraj himself by this title of gentility)," "every Dwadasi day, that is, the day following the Ekadasi." More interestingly perhaps, a somewhat cryptic allusion - cryptic, that is, for a non-Hindu reader ("One blurted out, 'Even the father of Lord Mahadeba can't catch a clever fellow stealing a drink of water after dipping into it"') — is fully explained by Das (1967: 2):

One of them, an accomplished wag, was even heard to say that if you dive under water for a holy ablution ostensibly to inaugurate an Ekadasi fast and then choose to quaff perfidiously under cover of water, even Lord Mahadev who, with his all-surveying eye, is believed to be infallibly omniscient will never be able to know and punish your sub-aquatic profanity.

The allusion is expanded and explained, as one line grows to five. And as the passage progresses further, references are added in this same chapter to, among other things, English Common Law, Section 60 of the Indian Evidence Act, Oliver Twist, Dr. Johnson, the Gospel of St-John, and Wordsworth's "Michael", none of which appear in the original text!

For which readers is Das writing? The truly creative nature of this translative act prevents us from limiting possible readers to those with a knowledge of English (i.e. British) literature (thus the additional references) but with little awareness of Indian, and more specifically Hindu, customs and practices (thus the explanations), that is, British 
continental readers. A number of indices work against such an hypothesis, most notably the decision to publish the translation in Cuttack, with the result that it is extremely unlikely it would ever be read elsewhere than in Orissa, or even there, since the translation is now unobtainable. But in addition to this, the baroque nature of the translation, its playful attitude towards the original, its embroidery and elaboration on the text being translated, all situate the translation within the Indian tradition of "transcreation", a term used to describe what Alexander Fraser Tytler once referred to as "translation with latitude." 22

The third translation is that by Nuri Misra, published in 1969. In his preface he briefly sets out his aims in the translation: he wishes to provide a text which will be accessible to a "reader for whom English is a second language." But is this reader necessarily, as one might expect, an Indian reader whose mother tongue is not Oriya? This can be put into doubt if the terms contained in the glossary accompanying the translation are any indication, as it includes definitions of such pan-Indian terms as 'Brahmin', 'lathi', 'pan', 'puja' and 'tulsi', in addition to various weights, measures and units of currency, some specific to Orissa ('guntha', 'mana') others not ('krosa', 'maund', 'seer'). The inclusion in the glossary of the English word 'mile' makes it even more difficult to identify the readership for which the translation was carried out, since it is unlikely that many of the intended readers would require an explanation of such a common word. A number of the definitions emphasize the relation of the term to Hinduism ("Mahastami - A day of religious observance of the Hindus"; "Satya Juga - Fair age. This is the 1st era according to the Hindu theory of evolution [...]"). Such definitions would seem to define the readers as non Hindus. In the end, perhaps the readership of this translation has simply not been clearly defined by the translator except in terms of the level of English to be employed.

Finally, who are the readers for whom the translation presently under revision is being produced? The translators are conscious of a variety of possible readerships, both national, within Orissa itself, and international. Their attempt has therefore been to produce a translation which presents as few obstacles as possible to readers outside India while at the same time firmly anchoring the text within its original context. These somewhat contradictory aims have led to the production of a hybrid text which at one and the same time both marks and elides cultural difference. It is precisely this contradiction which has given rise to the considerations contained in this paper.

\section{CONCLUSION}

Difference, and more specifically cultural difference, is at the very heart of the practice of translation; it is because difference exists that translation is required and because difference can be negotiated that translation is possible. Such negotiation is nevertheless exceedingly complex, and it is where languages, texts, and cultures meet somewhat problematically that translation is of particular interest, since it is precisely in those places that difference and the negotiation of difference come into our consciousness. We become aware not only of the necessity to translate the other into our own terms, but also that such translation, to a greater or lesser extent, does violence both to the other who is translated and to ourselves. It is with such awareness that this violence can be reduced. The forms such negotiation can take have been the subject of this paper, through the discussion of the status of (translation into) English in post-independence India, of the non translation (rather than the non translatability) of certain terms, and of the question as to the way culturallyspecific terms and allusions are variously dealt with by the different translators of Fakir Mohan Senapati's Chha Mana Atha Guntha. Our purpose has not been to assess the particular versions nor to posit an ideal form for the transformation of the original brought about through translation; rather it has been to examine the possible effects particular translations - including our own - can have, such effects, like so many symptoms, pointing to areas both of contact between languages and cultures, and to their differences. 


\section{Notes}

1. The research for this paper was carried out under a grant from the Social Sciences and Humanities Research Council of Canada. I would like also to express my thanks to Santosh Kumar Padhy for his help.

2. Marie-Claude Frédéric Étienne Vaultier, in his thesis, "De la traduction", presented to the University of Paris in 1812, defines 'translation' as a form of 'transportation': "Le mot traduction, dans son sens propre, devrait être à peu près synonyme de transport: il ne signifie étymologiquement que l'action de conduire ou de porter au-delà. [...] L'usage l'a appliqué et au procédé par lequel on transporte un ouvrage d'une langue dans une autre, et au genre de composition littéraire qui naît de ce procédé. Traduire, c'est donc opérer cette espèce de transport." (1812:1) [The literal meaning of the word translation should be more or less synonymous with transportation: etymologically it means the action of conducting or carrying beyond. [...] Through usage it has been applied both to the procedure through which a work is transported from one language into another, and to the literary composition which results from this. To translate is thus to carry out this sort of transportation. (My translation)].

3. Vaultier writes: "De ces différences radicales, naissent dans toutes les langues une foule de différences d'effets particuliers auxquels la traduction ne peut que difficilement atteindre : la traduction est donc un travail compliqué et difficile de sa nature; c'est de cette difficulté même que résulte son utilité." (1812:2) [From these radical differences result in all languages many different particular effects which translation can reproduce only with great difficulty: translation is thus by its very nature complicated and difficult, and it is from this very difficulty that its usefulness derives. (My translation)].

4. See in particular Brisset (1990) and Sherry Simon (1989 and 1995). Jane Koustas, in her recent work (see Koustas 1995), has also demonstrated the ideological nature of translation within the Canadian context, and in particular the effects of translation on the reception of Québécois works in English Canada, showing how the selection of works for translation into English creates a separate canon from that existing in Québec. For a treatment of the relation between translation and ideology, see in particular St-Pierre (1978/1979), as well as St-Pierre (1993 and 1995) for discussions of this relationship in connection with the history of translation.

5. This is clearly borne out by the one-sidedness of the translational relations between two contiguous constitutionally-recognized Indian languages, Bengali and Oriya (the language in which the novel under discussion here was written). More than ten times more works have been translated from Bengali into Oriya than in the other direction. The inequality of such relations can be explained in various ways; most notably, the concerted effort on the part of Bengalis to annex Orissa politically, culturally and territorially, to the point of attempting to deny, in the mid-nineteenth century, to Oriya any linguistic specificity or literary interest. See St-Pierre (1997) for further information on the question of translation in India.

6. As the narrator of Chha Mana Atha Guntha remarks in Chapter 8: "With a sharp and pitiless pen God has inscribed a strange fate for India: yesterday the language of the court was Persian, today it is English. Only He knows which language will follow." [Translation by R. S. Mishra, et al.]

7. This is underscored by the marginalization of English as spoken in India by the lexicographers of "standard" (read, "British" and/or "American") English, where the regional nature of these particular dialects (British or American) is at the very least not clearly indicated. See the latest Indian edition of the Oxford Advanced Learner's Dictionary of Current English, with its "Indian English Supplement," containing 2531 entries. The supplement is available exclusively in the edition printed in India.

8. See Trivedi (1993) and Sujit Mukherjee (1994) for a discussion of the implications of the choice of English, and of which English, as a medium of creation and of translation.

9. The phenomenon alluded to here - reading the literature of one's mother tongue in English translation is unfortunately on the rise. The education of Oriyas in English-medium (English-language) schools, with the prestige which comes from such an education, is increasingly having the effect of alienating students from their own language. This is the case is other parts of India as well.

10. Consider, for example, the following passage from Chapter 12, where a description of Asura Pond and the wildlife using it is provided: "Some sixteen to twenty cranes, white and brown, churn the mud from morning till evening, like lowly farmhands [...]. A pair of kingfishers suddenly arrive out of nowhere, dive into the water a couple of times, stuff themselves with food, and fly off in an instant. Sitting on the bank a kingfisher suns itself, its wings spead like the gown of a memsahib. O stupid Hindu cranes, look at these English kingfishers, who arrive out of nowhere with empty pockets, fill themselves with all manner of fish from the pond, and then fly away. You nest in the banyan tree near the pond, but after churning the mud and water all day long you get only a few miserable small fish. You face a critical time now: more and more kingfishers will swoop down on the pond and carry off all the best fish [...]." And immediately after this passage, the object of the narrator's satire changes to the Brahmins: "The kite is smart and clever; it perches quietly on a branch, like a Brahmin guru. It snatches a big fish in one quick swoop into the pond, and that is enough for it for the whole day. The Brahmin gurus never step down from their verandahs; they descend on their disciples once a year, like the kite." 
11. This translation, carried out by R. S. Mishra and J. K. Nayak, and revised by S. P. Mohanty and myself, is presently being prepared for publication. The passages cited correspond to the present state of the translation, which is still undergoing a constant process of revision and rewriting and is subject to change.

12. For transliteration as representation see the article by Paula Richman and Norman Cutler, "A Gift of Tamil: On Compiling an Anthology of Translations from Tamil Literature," in Meier and Dingwaney (1995: 245-266).

13. "Foreign", between quotation marks, since not discussed here are the degrees to which a reality can be considered foreign - that is, where the foreign is perceived as beginning - nor the question of the reference point, often implicit, in terms of which something may, or may not, be considered as such.

14. See Appendix 1 for the different translations of the passage under discussion.

15. A literal translation of the passage would read as follow: Jesus Christ - two pieces - bread with twelve-hundred people — fed, - and even — four baskets - left over were. — Kamyaka forest in — Shri Krushna - Durbasa's - twelve thousand - disciples' - stomach — little - spinach with - filled - had.

16. See the following account of the miracles of the loaves and the fishes in The Jerusalem Bible, the Gospel According to Saint John: “One of his disciples, Andrew, Simon Peter's brother, said, 'There is a small boy here with five barley loaves and two fish; but what is that between so many?' Jesus said to them, 'Make the people sit down.' There was plenty of grass there, and as many as five thousand men sat down. Then Jesus took the loaves, gave thanks, and gave them out to all who were sitting ready; he then did the same with the fish, giving out as much as was wanted. When they had eaten enough he said to the disciples, 'Pick up the pieces left over, so that nothing gets wasted'. So they picked them up, and filled twelve hampers with scraps left over from the meal of five barley loaves."

17. Literal translation: Hey! Hey! Those - slanderers - Christ - cross - ascend made, - extremely chaste - Sita - forest to - sent [...].

18. Literal translation: Such - has been heard, - his - aunt - son - Shyama - Malla - town to - gone had. - Sin - hidden - stay - does not. - He — bad company into - falling - onion mixed — cabbage/ cauliflower - eating - Saanta's near - unknown - stayed not.

19. The translator writes: "There is, however, much in my work which, by design, corresponds to Dr. Johnson's verdict on Alexander Pope's English translation of Homer's Iliad, 'Homer doubtless owes to his translator many Ovidian graces not exactly suitable to his character; but to have added can be no great crime, if nothing be taken away. Elegance is surely to be desired, if it be not acquired at the expense of dignity."' (1967: i)

20. See St-Pierre (1996) for a presentation of translation as writing.

21. "Shakespeare's status, popularity and dissemination in the post-colonial India of today, nearly half a century after independence, is determined to a large extent by a non-literary factor, just as it was in colonial India. Then it was the Empire; now it is ELT, or the hegemony of English as the pre-eminent international language. English is not only the world language which the whole of the non-English speaking world is under increasing economic and cultural pressure to learn; in India, it is also, because of a post-colonial realisation of the value of our colonially derived advantage in this respect, one of the two [sic] official languages of India, together with Hindi. About $40 \%$ of the population knows Hindi and only $2 \%$ knows English, but it is this tiny minority which is the privileged, prosperous, decision-making new ruling caste of the country." (Harish Trivedi 1994: 33-34).

22. The term "transcreation" occurs frequently in the discussion of translation in India, despite no strict definition of what it actually consists in. Paternity of the term is usually attributed to P. Lal but has recently been claimed by Saha. As for Tytler's expression, it is to be found in his Essays on the Principles of Translation, published in 1796 .

\section{REFERENCES}

1. Translations of Chha Mana Atha Guntha

DAS, C. V. Narasimha (1967): The Stubble Under the Cloven Hoof, Cuttack, Sahitya Samsad.

MISHRA, Rabi Shankar and Jatindra K. NAYAK, revised by S. P. Mohanty and Paul St-Pierre (forthcoming): Property and Theft. A Novel of Colonial India.

MISRA, Nuri (trans.) (1969): A Plot of Land, Cuttack, Cuttack Student's Store.

SENAPATI, B. M. and A. M. SENAPATI (1967): Six Acres and a Half, New Delhi, Publications Division of the Ministry of Information and Broadcasting.

2. Critical Works

BRISSET, Annie (1990): Sociocritique de la traduction. Théâtre et altérité au Québec (1968-1988), Longueil, Les Éditions du Préambule.

DEVI, Mahasweta (1995): Imaginary Maps, translated and introduced by Gayatri C. Spivak, London, Routledge. HANKIN, Nigel B. (1994): Hanklyn-Janklin, New Delhi, Banyon Books. 
HORNBY, A. S. (1996): Oxford Advanced Learner's Dictionary of Current English, Jonathan Crowther (Ed.), Fifth edition with a special supplement of Indian English, New Delhi, Oxford University Press.

KOUSTAS, Jane (1995): "Made in Quebec, Reviewed in Toronto: Critical Response to Translated Quebec Theatre", META, 40 (4), pp. 529-539.

LAL, P. (1972): Transcreation, Two Essays.

LÉVI-STRAUSS, Claude (1961): La Pensée sauvage, Paris, Plon.

LEWIS, Ivor (1992): Sahibs, Nabobs and Boxwallahs. A Dictionary of Words of Anglo-India, Bombay, Oxford University Press.

MEIER, Carol and Anuradha DINGWANEY (1995): Between Languages and Cultures. Translation and CrossCultural Texts, Pittsburgh, University of Pittsburgh Press.

MUKHERJEE, Sujit (1994): Translation as Discovery and Other Essays on Indian Literature in English Translation, Second edition, Hyderabad, Orient Longman.

ST-PIERRE, Paul (1978/1979): "Traduction et idéologie : une première approche", Langues et linguistique, 4-5, pp. 65-79.

ST-PIERRE, Paul (1993): "Translation as a Discourse of History", TTR, VI (1), pp. 61-82.

ST-PIERRE, Paul (1995): "L'orient traduit en français : l'autre transposé", La traduction en France à l'âge classique, Michel Ballard et Lieven D'hulst (dir.), Lille, Presses universitaires du Septentrion, pp. 177-206.

ST-PIERRE, Paul (1996): "Translation as Writing Across Languages: Samuel Beckett and Fakir Mohan Senapati", TTR, IX (1), pp. 233-254.

ST-PIERRE, Paul (forthcoming 1997): "Theory and Practice: Translation in India", Manchester, St. Jerome Press.

SAHA, P. K. (1995): "Translating Indian Literary Texts into English", Literary India. Comparative Studies in Aesthetics, Colonialism and Culture, P. C. Hogan and L. Pandit (Eds), Albany, State University of New York Press.

SAMAL, J. K. (1989): History of Modern Orissa, Calcutta, Firma KLM Private Limited.

SIMON, Sherry (1989): L'inscription sociale de la traduction au Québec, Québec, Office de la langue française.

SIMON, Sherry (Ed.) (1995): Culture in Transit. Translating the Literature of Quebec, Montréal, Véhicule Press.

TRIVEDI, Harish (1993): Colonial Transactions. English Literature and India, Calcutta, Papyrus.

TYTLER, Alexander Fraser (1978): Essays on the Principles of Translation, Amsterdam Classics in Linguistics, vol. 13, Jeffrey F. Huntsman (Ed.), Amsterdam, John Benjamins.

VALLTIER, Marie-Claude Frédéric Étienne (1812): "De la traduction", Thèse de littérature ancienne et modeme présentée à la Faculté de lettres de l'Académie de Paris.

YULE, Henry and A. C. BURNELL (1994): Hobson-Jobson, New edition edited by William Crooke, Calcutta, Rupa and $\mathrm{Co}$.

\section{Appendix I: Opening paragraph}

\section{Passage 1}

[Translation by R. S. Mishra et al., Property and Theft. A Novel of Colonial India]

Ramachandra Mangaraj was a rural landlord, and a prominent moneylender as well. His transactions in grain far exceeded those in cash. For an area of four kos around no-one else's business could thrive. The man was also quite pious. There are twenty-four ekadasis in a year; if there were forty, he would not have ignored a single one - this we need to acknowledge. He fasted every ekadasi and took nothing but water and a few leaves of the sacred basil plant for the entire day.

\section{Passage 2}

[Translation by B. M. Senapati and A. M. Senapati, Six Acres and a Half]

Ramchandra Mangaraj was a mofussil* Zamindar. He carried on an extensive business in lending paddy and money. Rumour goes that within a radius of eight miles no one eise had so much money-lending business. Mangaraj was a pious man who observed all the 24 Ekadashi fasts over the year. Had there been 40 a year, he would not have missed a single one either. On the day of the Ekadashi fast, he partook only of the leaves of sacred Tulasi with water.

*That is to say, living in the countryside, unlike many big ("absentee") landlords who lived in the metropolis, Calcutta, or at least in big towns like Cuttack.

Passage 3

[Translation by C. V. Narasimha Das, The Stubble under the Cloven Hoof]

The devil can cite Scripture for his purpose.

An evil soul, producing holy witness, 
Is like a villain with a smiling cheek;

A goodly apple rotten at the heart:

$\mathrm{O}$, what a goodly outside falsehood hath!

The Merchant of Venice (Act I, Sc. 3)

At once an estate-holder and a money-lender, Ramachandra Mangaraj has chosen to ply his business in the money-lending line by advancing the bulk of his loans in the shape of grain rather than of money. There is a consensus of opinion among the competent judges of Govindapur, who do not draw the long bow, that over eight long miles around that village the professional sway of the Samant (we mean Mangaraj himself by this title of gentility) is absolute. But the sheet-anchor of his life is his profound piety which, like his professional sway, has evoked at once the envy and despair of all men. Indeed his moral loftiness springs from his devout temper and, of course, also from his wisdom which is deeply routed in the fear of the Lord. There are two Ekadasi days in the course of each month of the Hindu calendar, one coming up during the dark fortnight and the other during the bright fortnight. It follows, therefore, that there are twenty-four Ekadasai days in all in the year; and it is around them that a good deal of Hindu piety collects itself generally. But if there had been forty Ekadasi every year instead, it would have been impossible for us to say that one out of them slipped away without finding the Samant in the grip of his devotional ardours. We must remember that water, consecrated with the Tulasi leaf, (that is, the Indian basil), is the only sacramental potation that sustains the great devotee on all Ekadasi days.

Passage 4

[Translation by Nuri Misra, $A$ Plot of Land]

Rama Chandra Mangaraj was a village Zamindar. He was also a creditor who used to lend money and paddy as well. He had no equal in wealth within krosas of his village. He was a pious man and observed all the 24 fasting days around the year. Had there been 40 such days, he would not have missed any one. On such fasting days he only took the sacred tulsi leaves.

\section{Passage 5}

Ramachandra Mangaraj was a rural landlord, and a prominent moneylender as well. His transactions in grain far exceeded those in cash. For an area of eight miles around no-one else's business could thrive. The man was also quite pious. There are twenty-four fasting days in a year; if there were forty, he would not have ignored a single one - this we need to acknowledge. He fasted on these days and took nothing but water and a few leaves of the sacred basil plant for the entire day.

\section{Passage 6}

Ramachandra Mangaraj was a mofussil Zamindar, and a prominent money-lender as well. His transactions in paddy far exceeded those in cash. For an area of four kos around no-one else's business could thrive. The man was also quite pious. There are twenty-four ekadasis in a year; if there were forty, he would not have ignored a single one - this we need to acknowledge. He fasted every ekadasi and took nothing but water and a few tulsi leaves for the entire day. 

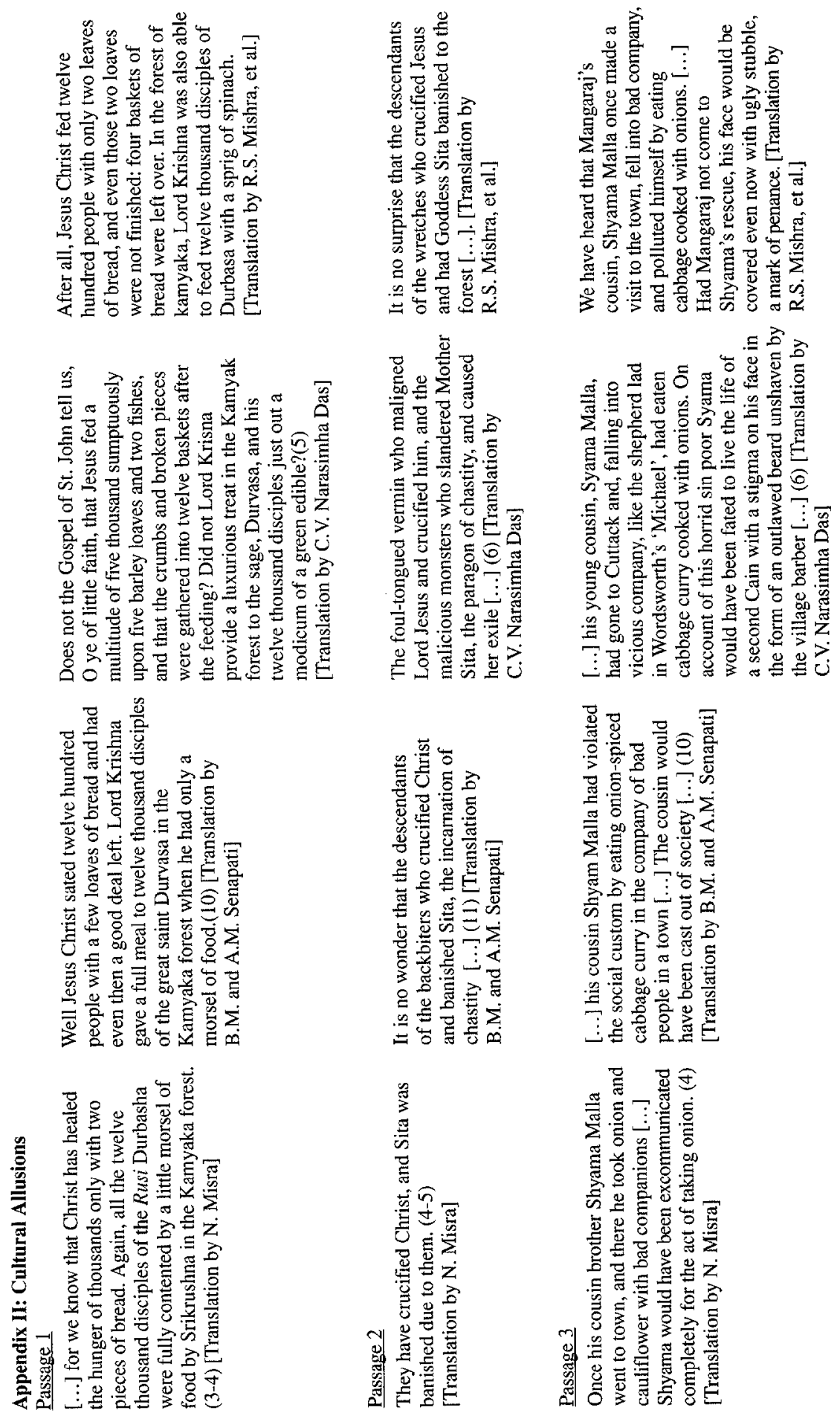